\section{Rust Resistance in Linseed}

INVESTIGATIONS on physiological specialization in Melampsora lini (Pers.) Lév. and the genetics of resistance of Linum usitatissimum L. have been going on in the University of Sydney since $1940^{1-3}$.

The physiological race survey covering all the Australian States has been curtailed recently, while the differential series is being 'pure lined'; but fifteen races have been identified to date using Flor's original set of differential varieties and two additional Argentine varieties. A race attacking 'Ottawa $770 \mathrm{~B}$ ' appeared in Western Australia in 1949, and eliminates this variety as a promising immune parent.

Several races have been used in the genetical studies. Australian race $K$ has given results closely paralleling those described by Flor in the United States. 'Newland', 'Ottawa 770 B', 'Bombay', 'J.W.S.', 'Tammes Pale Blue' and 'Abyssinian' are unifactorial, and 'Bolley Golden' is bifactorial, for resistance to this race. The factors fall into the allelic sories postulated for them by Flor.

Australian race $A$ has given different results. 'Bison', susceptible to all the races determined by Flor, carries a single dominant factor for resistance, probably falling in Flor's $L$ series. 'Ottawa $770 B$ ' and 'Newland' each carry one factor (apparently in the $N$ series) additional to those determined in the United States. The additional 'Ottawa' factor also operates against race $E$.

Uredospore germination is being intensively studied, and it has been found possible to obtain a more rapid and often a greater percentage germination of uredospores, stored at $3 \cdot 5^{\circ} \mathrm{C}$. for varying periods, by floating them on an aqueous seedling linseed extract. Consistently high percentage germinations (up to 80 per cent) have been given with spores of most races stored for eight months, and moderate germinations have been obtained up to fourteen months : in one case 25 per cent germination was obtained after seventeen months. A comprehensivo study of germination in relation to cold storage is now being undertaken, using several races of rust.

Twisted and variously shaped rings of coloured bell wire have been used to advantage in labelling plants showing different characters. The wire is available in at least six different colours, is very easily shaped, wears well, and is fairly cheap.

An excised shoot technique has been developed to facilitate the work. By this method shoots of linseed are excised above the cotyledons, placed in tap water or nutrient solution, and inoculated at once with uredospores. Normal rust reactions are obtained. Unless heavily infected, such shoots soon develop a root system, and may then be transplanted or left in situ to set seed. 'The efficiency of this technique is enhanced by the prolific branching of cut-back seedlings.

A number of advantages follow; for example, rapid clonal increase of valuable plants, testing of one plant with several races of rust simultaneously by forcing it to shoot from the base and excising the new shoots, standardization of plant nutrient medium, testing of one plant with an almost unlimited number of races, reduction in bench-space requirements, and so on.
Full details of the work will be published shortly. H, B. KmRR

Faculty of Agriculture, University of Sydney, Sydney, Aug. 29.

${ }^{1}$ Waterhouse, W. L., and Watson, I. A., Roy. Soc. N.S.W. J. and Proc., 75, 115 (1941); 77, 138 (1943). 2 Baker, E. P. (unpublished work).

s Charles, A. W. (unpublished honours thesis).

- Flor, H. H., J. Agric. Res., 74, 241 (1947).

\section{Autotetraploidy in Agrostis canina}

IN his revision of the British species of Agrostis, Philipson $^{x}$ subdivided Agrostis canina into the two varieties $A$. canina var. fascicularis and $A$. canina var. arida. These two varieties differ from one another in several morphological features, which are mainly of a quantitative nature ; but the basis of separation in Philipson's key is the presence of stolons in var. fascicularis and of rhizomes in var. arida. These varieties can be separated also by their ecological preferences. Var. fascicularis is commonly found on wet acid soils, and var. arida on the drier acid soils. Both varieties may, however, occur together.

Two chromosome numbers have been reported for Agrostis canina, namely, $2 n=14$ (Sokolovskaya) $^{2}$ and $2 n=28$ (Wulff) ${ }^{3}$. These numbers, however, were not associated with the two varietal types. More recently, Björkman ${ }^{4}$ has reported $2 n=14$ for var. fascicularis, and $2 n=28$ for var. arida.

The plants used by my colleague, Mr. W. Ellis Davies, for producing $F_{1}$ hybrids between the two varieties were also found to have the same numbers, and through his kindness I was able to examine the actual parents and their hybrids at meiosis.

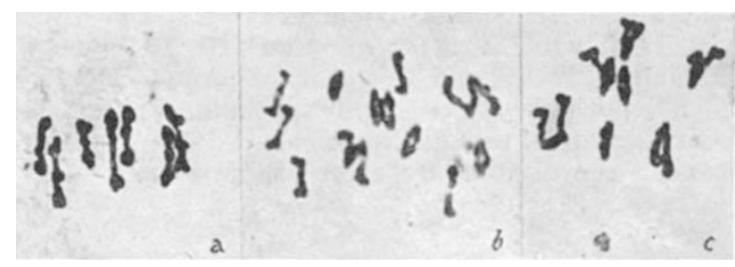

Photomicrographs of first metaphase of meiosis. (a) A. canina var. fascicularis, $7 \mathrm{II} ;\left(\right.$ b) A. canina var. arida, $3_{\mathrm{IV}} 8_{\mathrm{II}} ;\left(\right.$ (c) $F_{1}$ hybrid, $37 b R(1) 1(4), 1_{\mathrm{IV}} 4_{\text {III }} 2_{\text {II II }}$

The relevant data from these cytological investigations are contained in the accompanying table:

\begin{tabular}{|c|c|c|c|c|c|c|c|}
\hline \multirow[t]{2}{*}{ Plant } & \multirow{2}{*}{$\begin{array}{l}\text { Chromo- } \\
\text { some } \\
\text { number }\end{array}$} & \multirow{2}{*}{$\begin{array}{l}\text { Av. chiasma } \\
\text { freq. per } \\
\text { chromosome }\end{array}$} & \multicolumn{4}{|c|}{$\begin{array}{l}\text { Average MI conflguration } \\
\text { per pollen mother cell }\end{array}$} & \multirow{2}{*}{$\begin{array}{l}\text { No. } \\
\text { of } \\
\text { cells }\end{array}$} \\
\hline & & & I & II & III & IV & \\
\hline $\begin{array}{l}\text { A. canina var, fascicularis } \\
(\text { Bre } 343(14))\end{array}$ & 14 & 0.64 & $0 \cdot 11$ & $6 \cdot 94$ & 一 & 一 & 106 \\
\hline $\begin{array}{l}\text { A. canina var, arida } \\
(\text { Brc } 314(19))\end{array}$ & 28 & 0.71 & 0.34 & $10 \cdot 12$ & $0 \cdot 15$ & $1 \cdot 73$ & 72 \\
\hline $\begin{array}{rr}F_{1} \text { hybrids: } & \\
37 b R(1) & 1(4) \\
37 b R(1) & 2(3) \\
37 b R(1) & 13(4)\end{array}$ & $\begin{array}{l}21 \\
21 \\
21\end{array}$ & $\begin{array}{l}0 \cdot 68 \\
0 \cdot 67 \\
0 \cdot 70\end{array}$ & $\begin{array}{l}2 \cdot 17 \\
2 \cdot 85 \\
2 \cdot 10\end{array}$ & $\begin{array}{l}2 \cdot 20 \\
2 \cdot 85 \\
2 \cdot 13\end{array}$ & $\begin{array}{l}4 \cdot 77 \\
4 \cdot 14 \\
4 \cdot 83\end{array}$ & $\frac{0.02}{0.03}$ & $\begin{array}{l}36 \\
49 \\
30\end{array}$ \\
\hline
\end{tabular}

Whereas var. fascicularis behaves as a typical diploid, var. arida is characterized by the presence of 0-5 quadrivalents per pollen mother cell. As many as 13 per cent of the cells have four or five quadrivalents, indicating the potentiality for chromosome pairing in this variety. Thus we may consider that var. arida is probably an autotetraploid. The high average number of 4.0 quadrivalents per 